\title{
Plain packaging of tobacco products in the European Union: an EU success story?
}

\author{
Constantine Vardavas ${ }^{1,2}$, Filippos T. Filippidis $\mathbb{1}^{3}$, Brian Ward ${ }^{4}$, Marine Faure ${ }^{4}$, \\ Carlos Jimenez-Ruiz ${ }^{5}$, Christina Gratziou ${ }^{6,7}$, Paraskevi Katsaounou ${ }^{8}{ }^{8}$ on behalf \\ of the European Respiratory Society (ERS) Tobacco Control Committee ${ }^{10}$ and \\ Francisco Lozano9, Panagiotis Behrakis ${ }^{2,9}$, Cornel Radu-Loghin ${ }^{9}$ on behalf of \\ the European Network for Smoking and Tobacco Prevention (ENSP) Scientific \\ Committee ${ }^{11}$
}

\begin{abstract}
Affiliations: ${ }^{1}$ Faculty of Medicine, University of Crete, Clinic of Social and Family Medicine, Heraklion, Greece. ${ }^{2}$ Institute of Public Health, The American College of Greece, Athens, Greece. ${ }^{3}$ School of Public Health, Imperial College London, London, UK. ${ }^{4}$ EU Affairs Dept, ERS, Brussels, Belgium. ${ }^{5}$ Smoking Cessation Service of Region of Madrid, Madrid, Spain. ${ }^{6}$ Evgenidio Hospital, Smoking Cessation Centre, Athens, Greece. ${ }^{7}$ Medical School, National Kapodistrian University of Athens, Athens, Greece. ${ }^{8}$ Evangelismos Hospital, National and Kapodistrian University of Athens, Medical School, 1st ICU Dept, Athens, Greece. ${ }^{9}$ European Network for Smoking and Tobacco Prevention, Brussels, Belgium. ${ }^{10}$ For a list of the ERS Tobacco Control Committee members see the Acknowledgements section. ${ }^{11}$ For a list of the ENSP Scientific Committee Members see the Acknowledgements section.
\end{abstract}

Correspondence: Marine Faure, EU Affairs Dept, ERS, 49-51 Rue de Tréves, BE-1040 Brussels, Belgium. Marine.Fauredersnet.org

@ERSpublications

Plain packaging of tobacco products: an EU success story http://ow.ly/6oww30fH4DJ

Cite this article as: Vardavas C, Filippidis FT, Ward B, et al. Plain packaging of tobacco products in the European Union: an EU success story? Eur Respir J 2017; 50: 1701232 [https://doi.org/10.1183/ 13993003.01232-2017].

In March 2017, the European Union (EU) celebrated its 60th anniversary. The frenzied focus in recent times has been on crises, from economics to migration, terrorism and the UK leaving the EU. However, in contrast to the increase in Euroscepticism are the EU's successes, which should and must be celebrated. One of the major victories from a public health perspective is the harmonisation of tobacco control policy across the $28 \mathrm{EU}$ member states (MSs) through the Tobacco Products Directive (TPD) and the Tobacco Tax Directive, which, through the regulation of tobacco products, protect the health of the 511 million EU citizens.

Tobacco smoking is the main preventable cause of morbidity and mortality from lung cancer, chronic obstructive pulmonary disease and coronary artery disease [1]. It causes $>6$ million deaths each year globally [2] and is responsible for 700000 deaths every year in the EU [3]. In addition, the burden of tobacco use on society is enormous. In Europe, a report from the European Commission in 2012 suggested that tobacco-related diseases cost the economy EUR 544 billion in 2009, which is equivalent to $\sim 4.6 \%$ of the EU's gross domestic product [4]. Hence, the economic benefits of tobacco control are enormous.

The EU has made great progress in de-normalising tobacco use, encouraging smokers to quit, protecting nonsmokers from second-hand smoke and preventing young people from taking up smoking [5]. This is corroborated by the prevalence trends from 2006-2015 that show a decline in the proportion of smokers

Received: June 212017 | Accepted after revision: Oct 022017

Conflict of interest: B. Ward and M. Faure are employees of the European Respiratory Society.

Copyright OERS 2017 
of six percentage points in the $\mathrm{EU}$ as a whole [6]. However, a lot remains to be done. The number of smokers in the EU continues to be of concern, with $26 \%$ of the overall population and $25 \%$ of young people aged 15-24 years being current smokers [7].

Policies on cigarette packaging and labelling are constantly gaining momentum in the EU and worldwide, and are proven tobacco control tools. Since May 20, 2016, the EU TPD has required that all EU MSs include pictorial warnings on cigarette packs that cover $65 \%$ of the external front and back surface of the unit packet, and any outside packaging of cigarettes and roll-your-own tobacco [8]. The increased size of the pictorial warnings is a significant step forward in tobacco control; however, plain packaging represents one step ahead in reducing the tobacco industry's marketing outreach to our youth.

Although many factors influence tobacco experimentation and use, a number of studies have shown that tobacco industry advertising and promotion stand out as a prominent factor in encouraging tobacco use [9]. Cigarette packaging, including the pack format (size, shape and opening), colours and logos, impact consumer perception of health risks of smoking [10-15]. The whole purpose of plain packaging is to thwart this industry tactic.

Plain packaging strips cigarette packs of all branding elements, including colours and logos, and mandates that all cigarette packaging be a standardised colour and display only a brand name in a required font style and format. Plain packs are not white or blue but an indifferent hue of brown. In other words, plain packaging removes the mask of marketing from the packet and reveals the true nature of tobacco: a product that kills up to half of its users [2].

In light of the above, the European Respiratory Society (ERS), together with the European Network for Smoking and Tobacco Prevention (ENSP), jointly developed a position paper to reaffirm the scientific evidence behind plain packaging and encourage countries to implement the measure. The document was presented at a high-level event in the European Parliament in Brussels, Belgium, to various stakeholders such as policy makers, nongovernmental organisations, health professionals and academics, as part of World No Tobacco Day 2016. This position paper can be summarised in four key points that put forward the arguments in favour of plain packaging: 1) plain packaging works; 2) plain packaging is cost-effective; 3) plain packaging is legal; and 4) plain packing is happening.

\section{Plain packaging works}

Scientific evidence has shown that the implementation of plain packaging reduces smoking prevalence [16], increases thoughts about quitting and calls to quit lines [17, 18], reduces brand awareness, attractiveness and appeal of the package [19-21], and increases the salience and effectiveness of health warnings among adolescents [22]. Moreover, despite claims of the opposite, the implementation of plain packaging does not impact illicit trade or product retrieval time [23-25].

To strengthen the current evidence behind plain packaging, it is important that all EU MSs evaluate the impact of the implementation of the measure in their region and for their national population. Regional evidence is warranted to expand further the evidence base that supports the implementation of plain packaging.

\section{Plain packaging is cost-effective}

EU MSs should require plain packaging because the measure is a cost-effective public health policy for governments. Indeed, the state determines the regulation but costs related to tobacco packaging implementation are borne by the tobacco industry [26].

\section{Plain packaging is legal}

The political setting to implement plain packs is provided by international agreements such as the World Framework Convention on Tobacco Control (WHO FCTC), by the World Trade Organisation (WTO), through the Trade Related Aspects of Intellectual Property (TRIPS) and by European legislation through the EU TPD. The WHO FCTC states that "Parties should consider adopting plain packaging requirements to eliminate the effects of advertising or promotion on plain packaging" [27]. In the Doha declaration on the TRIPS agreement and public health, WTO members agreed that "the TRIPS agreement does not and should not prevent member states from taking measures to protect public health" [28].

The TPD does not require EU MSs to implement plain packaging but it specifies in Article 24.2 that member states are permitted to implement the measure. This was confirmed by a ruling from the European Court of Justice on May 4, 2016, which deemed that the Directive was valid on all points, including the right of EU MSs to introduce plain packaging [29]. This crucial ruling prevents the various legal proceedings brought at national levels by the tobacco industry from ever being successful. 


\section{Plain packaging is happening}

Currently, a number of countries have either introduced plain packaging legislation or have publicly expressed their interest in implementing it. Australia was the first country to adopt the measure and implement it in 2012 [30] followed by France, which implemented the measure from December 31, 2016 [31]. In the UK [32] and Ireland [33], plain packaging has been in force as of May 2017; Hungary will implement plain packaging in 2018 [32] and Slovenia. in January 2020 [34]. A number of other countries have already taken strong steps in the legislation process or formally considered introducing the measure, such as Norway, New Zealand, Canada, Uruguay, Thailand, Singapore, Belgium, Romania, Turkey, Finland, Chile and South Africa [32].

Plain packaging alone is obviously not a silver bullet to reduce smoking-related deaths but the ERS and the ENSP believe that it has to be part of the solution. Plain packaging should be implemented together with a set of evidence-based measures including product regulation, smoke-free legislation, increased taxation, banning of direct and indirect tobacco advertising, promotion and sponsoring, banning of vending machines for all cigarettes, and the development of smoking cessation services. However, all of these public health measures are only achievable in the EU framework, which allows cross-border cooperation and provides a strong legal basis to support EU MSs. One day, we will see every EU MS adopt plain packs. This, like the EU's 60th birthday, will be a cause for celebration.

In 2016, the ERS and the ENSP launched a campaign to encourage MSs to implement plain packaging, first, by organising a high-level awareness-raising event at the European Parliament, and secondly, by promoting a short video showing the benefits of the measure in protecting younger population. This video is available from https://www.ersnet.org/advocacy/eu-affairs/plain-packaging-protects-our-youth-supportthe-campaign

\section{Acknowledgements}

The ERS Tobacco Control Committee members are Carlos Jimenez-Ruiz, Christina Gratziou, Constantine Vardavas, Sofia Ravara (Faculty of Health Sciences, University of Beira Interior and CHCB University Hospital, Covilhã, Portugal), Bo Lundbäck (Krefting Research Centre, Institute of Medicine, University of Gothenburg, Gothenburg, Sweden), Paraskevi Katsaounou, Dick Heederik (Institute for Risk Assessment Sciences, Division Environmental Epidemiology, Utrecht, the Netherlands), Dan Smyth (European Lung Foundation, Sheffield, UK), Werner Bill (ERS, Lausanne, Switzerland) and José Ignacio de Granda (Respiratory Dept, 12 October University Hospital, Medical School of Complutense University, Madrid, Spain). The ENSP Scientific Committee Members are Panagiotis Behrakis, Bertrand Dautzenberg (Groupe hospitalier Pitié-Salpétrière, Paris, France), Luke Clancy (TobaccoFree Research Institute Ireland, Dublin, Ireland), Nazmi Bilir (Hacettepe, University Institute of Public Health, Ankara, Turkey), Manfred Neuberger (Medical University of Vienna, Vienna, Austria), Andrey Demin (Russian Public Health Association, Moscow, Russia), Jørgen Falk (ENSP, Brussels, Belgium) and Francisco Javier Ayesta (University of Cantabria, Santander, Spain).

\section{References}

1 Gibson GJ, Loddenkemper R, Sibille Y, et al., eds. The European Lung White Book. 2nd Edn. Sheffield, European Respiratory Society, 2013.

2 World Health Organisation. Tobacco. www.who.int/mediacentre/factsheets/fs339/en/ Date last updated: May 2017. European Commission. Tobacco. https://ec.europa.eu/health/tobacco/policy_en

The European Commission. A study on liability and the health costs of smoking, DG Sanco. http://ec.europa.eu/ health//sites/health/files/tobacco/docs/tobacco_liability_final_en.pdf Date last updated: April 2012.

5 The ASPECT Consortium. Tobacco or Health in the European Union: Past, Present and Future. http://ec.europa. eu/health/archive/ph_determinants/life_style/tobacco/documents/tobacco_fr_en.pdf Date last updated: October 2004.

6 European Commission. Special Eurobarometer 322: Tobacco. http://ec.europa.eu/health//sites/health/files/tobacco/ docs/ebs332_en.pdf Date last updated: May 2010.

7 European Commission. Special Eurobarometer 429: Attitudes of Europeans towards tobacco and electronic cigarettes. http://ec.europa.eu/public_opinion/archives/ebs/ebs_429_en.pdf Date last updated: May 2015.

8 European Parliament, European Council. Directive 2014/40/EU of the European Parliament and of the Council of 3 April 2014. Off J Eur Union 2014; L 127/1-L 127/38.

9 Henriksen L. Comprehensive tobacco marketing restrictions: promotion, packaging, price and place. Tob Control 2012; 21: 147-153.

10 Bansal-Travers M, Hammond D, Smith $\mathrm{P}$, et al. The impact of cigarette pack design, descriptors, and warning labels on risk perception in the US. Am J Prev Med 2011; 40: 674-682.

11 Borland R, Savvas S, Sharkie F, et al. The impact of structural packaging design on young adult smokers' perception of tobacco products. Tob Control 2013; 22: 97-102.

12 Brown A, McNeill A, Mons U, et al. Do smokers in Europe think all cigarettes are equally harmful? Eur J Public Health 2012; 22: Suppl. 1, 35-40.

13 Gendall P, Hoek J, Thomson G, et al. Young adults' interpretations of tobacco brands: implications for tobacco control. Nicotine Tob Res 2011; 13: 911-918.

14 Kotnowski K, Hammond D The impact of cigarette pack shape, size and opening: evidence from tobacco company documents. Addiction 2013; 108: 1658-1668.

15 Stead M, Moodie C, Angus K, et al. Is consumer response to plain/standardised tobacco packaging consistent with framework convention on tobacco control guidelines? A systematic review of quantitative studies. PLoS One 2013; 8: e75919. 

prevalence following the introduction of plain packaging in Australia. Tob Prev Cessation 2015; 1: https://doi.org/ $10.18332 / \mathrm{tpc} / 60650$.

17 Moodie C, Bauld L, Ford A, et al. Young women smokers' response to using plain cigarette packaging: qualitative findings from a naturalistic study. BMC Public Health 2014; 14: 812.

18 Young JM, Stacey I, Dobbins TA, et al. Association between tobacco plain packaging and Quitline calls: a population-based, interrupted time-series analysis. Med J Aust 2014; 200: 29-32.

19 Balmford J, Borland R, Yong HH. Impact of the introduction of standardised packaging on smokers' brand awareness and identification in Australia. Drug Alcohol Rev 2015 [in press https://doi.org/10.1111/dar.12331].

20 Brose LS, Chong CB Aspinall E, et al. Effects of standardised cigarette packaging on craving, motivation to stop and perceptions of cigarettes and packs. Psychol Health 2014; 29: 849-860.

21 Dunlop SM, Young JM, Perez D, et al. Impact of Australia's introduction of tobacco plain packs on adult smokers' pack-related perceptions and responses: results from a continuous tracking survey. BMJ Open 2014; 4: e005836.

22 Germain D, Wakefield MA, Durkin SJ. Adolescents' perceptions of cigarette brand image: does plain packaging make a difference? J Adolesc Health 2010; 46: 385-392.

23 Scollo M, Zacher M, Durkin S, et al. Early evidence about the predicted unintended consequences of standardised packaging of tobacco products in Australia: a cross-sectional study of the place of purchase, regular brands and use of illicit tobacco. BMJ Open 2014; 4: e005873.

24 Scollo M, Bayly M, Wakefield M. Availability of illicit tobacco in small retail outlets before and after the implementation of Australian plain packaging legislation. Tob Control 2015; 24 (e1): e45-e51.

25 Bayly M, Scollo M, Wakefield M. No lasting effects of plain packaging on cigarette pack retrieval time in small Australian retail outlets. Tob Control 2015; 24(e1): e108-e109.

26 Framework Convention Alliance. Packaging and Labelling. www.fctc.org/about-fca/tobacco-control-treaty/ the-work-of-the-fca/packaging-and-labelling

27 World Health Organisation. Framework Convention on Tobacco Control. Guidelines for implementation of Article 13 of the WHO Framework Convention on Tobacco Control (Tobacco advertising, promotion and sponsorship). Geneva, WHO, 2008.

28 World Health Organisation. Plain packaging of tobacco product: evidence, design and implementation. http://apps. who.int/iris/bitstream/10665/207478/1/9789241565226_eng.pdf?ua=1 Date last updated: 2016.

29 Court of Justice of the European Union. The new EU directive on tobacco products is valid. Press release, 4th May 2016. https://curia.europa.eu/jcms/upload/docs/application/pdf/2016-05/cp160048en.pdf

30 Australian Government. Introduction of plain packaging in Australia. www.health.gov.au/internet/main/ publishing.nsf/Content/tobacco-plain Date last updated: May 272016.

31 Ministère des Affaires sociales et de la Santé. Marisol Touraine publie le calendrier d'application du paquet neuter [Marisol Touraine publishes the timetable for implementation of plain packaging]. http://social-sante.gouv.fr/ actualites/presse/communiques-de-presse/article/marisol-touraine-publie-le-calendrier-d-application-du-paquetneutre Date last updated: March 22, 2016.

32 Canadian Cancer Society. Cigarette Package Heath Warnings: International Status Report. 5th Edn. www.cancer. $\mathrm{ca} / \sim / \mathrm{media} / \mathrm{cancer} . \mathrm{ca} / \mathrm{CW} /$ for\%20media/Media\%20releases/2016/CCS-international-cigarette-packaging-report2016-English.pdf?la=en Date last updated: October 2016.

33 Public Health (Standardised Packaging of Tobacco) Act 2015 (Commencement) Order 2016 (S.I. no. 270 of 2016).

34 WHO Implementation Database. Slovenia passes law to require plain tobacco packaging from 2020. http://apps. who.int/fctc/implementation/database/groups/slovenia-passes-law-require-plain-tobacco-packaging-2020 